\section{Seasonal Changes in Root Metabolic Activity and Nitrogen Uptake for Two Cultivars of Creeping Bentgrass}

\author{
Qingzhang Xu and Bingru Huang ${ }^{1}$ \\ Department of Plant Biology and Pathology, Rutgers University, New \\ Brunswick, NJ 08901
}

\section{Additional index words. Agrostis stolonifera, cultivar variation, temperature}

\begin{abstract}
Roots play important roles in plant responses to environmental changes. The objective of this study was to investigate seasonal changes and cultivar variation in root growth, respiratory activity, nitrogen uptake, and carbon allocation in relation to turf performance for two cultivars of creeping bentgrass [Agrostis stolonifera $\mathrm{L}$. var. palustris (Huds.)] under field conditions. Two cultivars, 'Penncross' and 'L-93', were managed under USGA-specification putting green conditions, with daily irrigation and mowing at a 3-mm height from May to November in 1999 and 2000. Turf quality of both cultivars declined from the highest rating of 7 to 9 in May to 4 to 5 in August and September, and recovered to above 7 in October and November in both years. This corresponded to seasonal changes in root dry weight, dehydrogenase activity, nitrate reductase (NR) activity, carbon allocation to roots, and ${ }^{15} \mathrm{~N}$ uptake. Compared to Penncross, L-93 generally maintained better turf quality, as well as higher root dry weight, ${ }^{15} \mathrm{~N}$ uptake, NR activity, and carbon allocation during summer months. Previous studies often emphasize the important of a large, extensive root system. The results in the present study demonstrated that root metabolic activities followed the same seasonal pattern and cultivars variation as turf performance, and suggested that decline in root metabolic activities could be contributed to summer decline in turf quality for creeping bentgrass.
\end{abstract}

The optimum temperature for root growth in cool-season grasses ranges from 10 to 18 ${ }^{\circ} \mathrm{C}$, and root growth of cool-season grasses decreases as temperature increases above the optimum level(Beard, 1973). Roots of creeping bentgrass exhibited seasonal growth patterns; total root length and number are greatest during the months of March through June, with a second (but smaller) period of increase occurring during October, and roots were smallest during summer (Huang and Liu, 2003; Karnok and Kucharski, 1980; Koski, 1983). Schlossberg et al. (2002) suggested that seasonal cumulative effect of temperature was more influential than instantaneous temperature causing summer root growth decline. Decline in the size of root system during summer for creeping bentgrass may be the result of a greater rate of root dieback than rate of new root production (Huang and Liu, 2003). Small root systems would limit uptake of water and nutrients as well as hormone production.

Most previous studies on seasonal rooting patterns in turfgrass focuses on root growth characteristics (length, weight, or number) (Huang and Liu, 2003; Karnok and Koski, 1983; Kucharski, 1980; Schlossberg et al., 2002; Sweeney et al., 2001), whereas limited information is available on seasonal changes in root metabolic activity and function for coolseason turfgrasses. Previous studies suggested that among root activities, nutrient uptake was one of the most sensitive processes in response

Received for publication 14 Oct. 2005. Accepted for publication $9 \mathrm{Feb} .2006$.

${ }^{1}$ Corresponding author; e-mail huang@aesop. rutgers.edu. to increasing temperatures in cool-season turfgrass species (Bushoven and Hull, 2001; Huang and $\mathrm{Xu}, 2000)$. Nitrogen assimilation largely depends on the activity of nitrate reductase (Bushoven et al., 2002). Nutrient uptake and assimilation were positively related to root respiratory activity and carbon supply from shoots to roots (Greef and Geisler. 1991; Sullivan et al., 2000). Roots are more sensitive to heat stress than shoots, and root growth decline has been shown to proceed shoot growth decline (Xu and Huang, 2000). Disturbances in root metabolic activities under high temperature conditions could lead to deterioration of shoot growth and physiological functions. Therefore, we hypothesized that variation in root metabolic activities are associated with changes in turf performance and differences in heat tolerance in cool-season turfgrasses.

The objective of this study was to investigate seasonal changes and cultivar variation in root respiratory activity, nitrate reductase activity, nitrogen uptake, and carbon allocation for creeping bentgrass. A better understanding of seasonal changes in root activity for creeping bentgrass could help determine timing of implementing management practices to promote active root activities and high quality turf or to alleviate summer decline of root metabolic activity and turf quality.

\section{Materials and Methods}

The experiment was conducted on an USGA-specification putting green at the Turfgrass Research Center, Manhattan, Kansas in 1999 and 2000. Two cultivars, 'L-93' and 'Penncross', were seeded in 205 $\times 318 \mathrm{~cm}$ plots in September 1996. Grass was mowed daily except Sunday at $3 \mathrm{~mm}$ in height from early May to early November in 1999 and 2000. During this period, the green was irrigated daily to replace $100 \%$ potential evapotranspiration rate, which was measured using mini-lysimeters. The green received four applications (May, July, September, and October) of total nitrogen of $98 \mathrm{~kg} \cdot \mathrm{ha}^{-1}$ in 1999 and $65 \mathrm{~kg} \cdot \mathrm{ha}^{-1}$ in 2000.

The two cultivars were arranged in a completely randomized block design with three replications. All measurements were taken periodically each month on two subsamples in each plot. Effects of cultivars and time of sampling were determined by analysis of variance according to the general linear model procedure of Statistical Analysis System (SAS Institute, Cary, N.C.). Differences between cultivar means and time of sampling were determined by the least significance difference (LSD) test at the 0.05 probability level.

Daily maximum air temperature (about $150 \mathrm{~cm}$ from the ground) was measured using thermocouples connected to a datalogger (CR10X; Campbell Scientific, Inc., Logan, Utah). Data were collected every $10 \mathrm{~min}$ and averaged as daily means.

Turf quality was visually rated based on color, uniformity, and density on a 1 to 9 scale, with $9=$ the best and $1=$ the worst. For the measurement of root dry weight, dehydrogenase activity, and nitrate reductase activity, soil cores of $5 \mathrm{~cm}$ in diameter and $20 \mathrm{~cm}$ deep were collected from field plots and roots were washed free of soil and collected for analysis. Each parameter was measured for roots collected from two soil cores in each plot.

Root dehydrogenase activity measures respiratory activity, which has been used to differentiate between live and dead tissue using tripenyltetrazolium chloride (TTC) reduction technique (Knievel, 1973). A $500 \mathrm{mg}$ of fresh roots were placed into test tubes with $0.6 \%$ TTC in $0.05 \mathrm{M} \mathrm{Na}_{2} \mathrm{HPO}_{4}-\mathrm{NaH}_{2} \mathrm{PO}_{4}$ buffer solution. Roots were incubated in a $30^{\circ} \mathrm{C}$ water bath in darkness for $20 \mathrm{~h}$, washed twice with water, and then extracted in $95 \%$ ethanol at $55^{\circ} \mathrm{C}$ for $2 \mathrm{~h}$. Absorbance was measured at $490 \mathrm{~nm}$. Root activity was expressed as absorbance/g fresh weight of roots in 20-mL ethanol solution.

Nitrate reductase activity of roots was determined using the method described by Bushoven and Hull (2001). A 250-mg sample of fresh roots were cut into $5 \mathrm{~mm}$ pieces and incubated at $30^{\circ} \mathrm{C}$ in $0.1 \mathrm{M}$ phosphate buffer and $1 \%$ n-prophanol with $0.05 \mathrm{M} \mathrm{KNO}_{3}(\mathrm{pH}$ was 7.5). The production of $\mathrm{NO}_{2}$ in darkness after 60 min was measured using Grease reagent $(1 \mathrm{~mL})$ containing $0.001 \mathrm{~g}$ 1-naphtyl-ethylene-diamin, $0.01 \mathrm{~g}$ sulphanilic acid, and $0.90 \mathrm{~g}$ tartaric acid. The amount of $\mathrm{NO}_{2}$ produced in $60 \mathrm{~min}$ was measured spectrophotometrically at 540 $\mathrm{nm}$. Nitrate reductase activity was expressed as $\mathrm{nmol} \mathrm{NO}_{2} / \mathrm{g} / \mathrm{h}$.

Nitrogen uptake was estimated using the ${ }^{15} \mathrm{~N}$ labeling technique (BassiriRad and Caldwell, 1992). A $22-\mathrm{cm}^{2}$ area of turf was isolated from the surrounding areas (to prevent lateral movement of ${ }^{15} \mathrm{~N}$ enriched $\mathrm{NH}_{4}{ }^{15} \mathrm{NO}_{3}$ solution) by installing a plastic tube $(5.3 \mathrm{~cm}$ in diameter 
and $20 \mathrm{~cm}$ deep) in the soil. Fifty $\mathrm{ml}$ of $2 \mathrm{mM}$ $\mathrm{NH}_{4}{ }^{15} \mathrm{NO}_{3}$ solution ( $5 \%$ of $\mathrm{N}$ atom enrichment) was slowly injected into the soil at 3 and $6-\mathrm{cm}$ depths in the isolated soil column. Four days after labeling, the labeled plants were harvested along with $20-\mathrm{cm}$ deep soil core. Roots were washed free of soil and were killed at $105{ }^{\circ} \mathrm{C}$ and dried at $70{ }^{\circ} \mathrm{C}$. Total $\mathrm{N}$ and ${ }^{15} \mathrm{~N}$ content in roots was determined. The ${ }^{15} \mathrm{~N}$ content was assumed to be a measure of root $\mathrm{N}$ uptake within the labeling (4 d) period (Thornton and Millard, 1996) Specific ${ }^{15} \mathrm{~N}$ content (ng $\cdot \mathrm{g}^{-1}$ dry weight) in roots was calculated using the following equation described in Millard and Neilsen (1989): (atom\% of sample $\left.{ }^{15} \mathrm{~N}-0.367\right) \times 10000 /$ dry weight. The atom $\%$ of sample ${ }^{15} \mathrm{~N}$ was measured using a mass spectrophotometer (Shimadzu Scientific Instruments Inc. Columbia, S.C.).

Carbon allocation to roots was determined using pulse ${ }^{14} \mathrm{CO}_{2}$ labeling technique as described by Huang and $\mathrm{Fu}$ (2000). Plant canopy was enclosed in a clear plexiglass chamber (5 $\mathrm{cm}$ tall and $10 \mathrm{~cm}$ in diameter) and exposed to $10 \mu \mathrm{Ci}{ }^{14} \mathrm{CO}_{2}$ for $20 \mathrm{~min}$. Three days after ${ }^{14} \mathrm{CO}_{2}$ labeling, shoots and roots were washed free of soil, killed at $105^{\circ} \mathrm{C}$ for $30 \mathrm{~min}$, and dried at $75^{\circ} \mathrm{C}$ for $48 \mathrm{~h}$. Twenty milligrams of sample was digested with $4 \mathrm{~mL}$ solublizing liquid (Solvable; Dupond, Wilminton, Del.) at $50{ }^{\circ} \mathrm{C}$ for $24 \mathrm{~h}$ and bleached with $0.1 \mathrm{~mL}$ of $30 \% \mathrm{H}_{2} \mathrm{O}_{2}$ for $1 \mathrm{~h}$ at $25^{\circ} \mathrm{C}$ (Huang et al. 1993). Fifteen milliliters of scintillation cocktail for ${ }^{14} \mathrm{C}$ counting were added to the solutions and were measured in a scintillation counter (Packard, Deers Grove, Ill.). The proportion of newly photosynthesized carbon that was allocated to roots was calculated.

\section{Results and Discussion}

Seasonal changes in air temperatures. Daily maximum air temperature exhibited clear seasonal patterns in both 1999 and 2000 (Fig. 1). It was averaged $24^{\circ} \mathrm{C}$ in May and increased to the highest level in July 1999 and August 2000. Highest temperature was $40^{\circ} \mathrm{C}$ at the end of July in 1999 and $43{ }^{\circ} \mathrm{C}$ at the end of August 2000. By October and November in both years, air temperature declined to below $24{ }^{\circ} \mathrm{C}$, similar to the level in May.

Seasonal changes in turf quality, root growth, and metabolic activities. Turf quality for L-93 and Penncross were at the highest level of 8.3 and 7.6 in May and June, respectively; the rating then declined to the lowest level of 5.8 and 5 in August 1999 (Fig. 2A) and of 6.0 and 4.0 in September 2000 for L-93 and Penncross, respectively (Fig. 2B). Turf quality recovered to an average of 8.6 and 7.1 in October and November in both years for L-93 and Penncross, respectively. Root dry weight also exhibited seasonal changes for both cultivars in both years (Fig. 3A and B), with a cultivar average of $40 \%$ decline

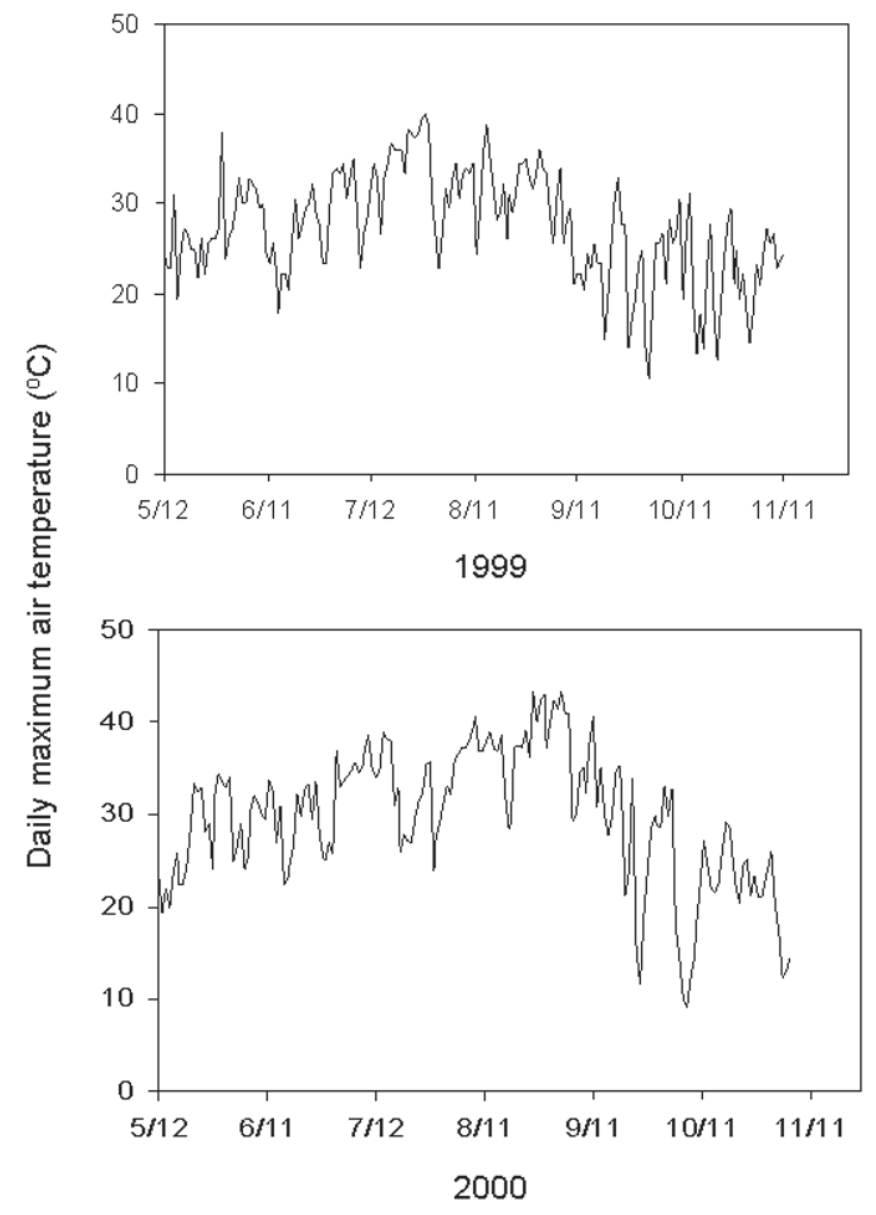

Fig. 1. Daily maximum air temperature from May to November in 1999 and 2000. from May to August in 1999 and 63\% from May to September 2000. The changes in root dry weight did not follow the same pattern as for turf quality in 1999. Previous studies have shown that turf quality decline during summer for creeping bentgrass was accompanied by a decline in root growth characteristics, and the timing of minimum root length, biomass, and number corresponded to the onset of turf quality decline in creeping bentgrass (Huang and Liu, 2003; Schlossberg et al., 2002; Sweeney et al., 2001). Our study also found that summer turf quality decline of creeping bentgrass may not only be related to decreases in root size as biomass or length, but also could be associated with the deterioration of root metabolic activities in terms of carbon supply or demand, dehydrogenase activity, and nitrogen uptake and assimilation, as discussed in the following sections. Seasonal changes in turf quality and root growth were closely related to seasonal temperature changes (Fig. 1), although other environmental factors such as relative humidity may also affect these parameters. Lowest turf quality (Fig. 2), root growth and activities (Fig. 3-7) were observed when air temperature reached the maximum in July and August in both years (Fig. 1), suggesting that temperature had significant impact on turf and root growth.
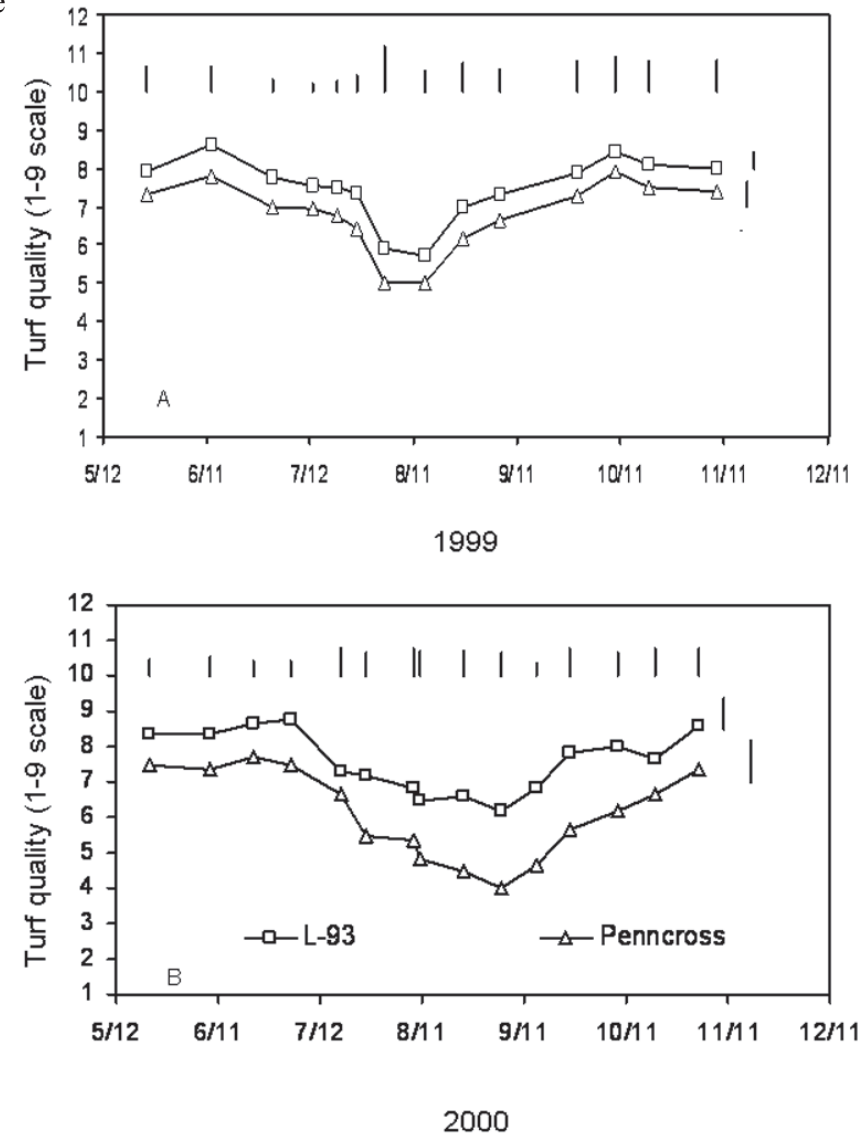

Fig. 2. Seasonal changes in turf quality for two creeping bentgrass cultivars, L-93 and Penncross, in 1999 (A) and 2000 (B). Turf quality was visually rate on the scale of 1 to 9 , with $9=$ the best. Vertical bars on the top indicate LSD values $(P<0.05)$ for cultivar comparison at a given date of year. Vertical bars on the right indicate LSD values $(P<0.05)$ for seasonal changes for a given cultivar. 
${ }^{14}$ Carbon allocation to roots for both cultivars was lowest in July and August 1999, accounting for $10.4 \%$ of total carbon fixation; the proportion of ${ }^{14} \mathrm{Carbon}$ in roots was highest $(15 \%)$ in May 1999 and October (13\%) (Fig. 4A). Similar patterns were found in 2000 , when the proportion of ${ }^{14} \mathrm{Carbon}$ in roots was $23 \%, 11 \%$, and $20 \%$ in June, September, and November 2000, respectively (Fig. 4B). The summer decline in ${ }^{14} \mathrm{C}$ allocation was more pronounced for Penncross than for L-93 in both years. The decrease in the proportion of ${ }^{14} \mathrm{C}$ allocation to roots suggested that the amount of newly photosynthesized carbon allocated to roots decreased in the summer, which could be related to the decline in root dry weight in summer months. This result also indicated that root demand for carbon or carbon metabolic activity decreased during summer months, because carbon supply from shoots to roots is largely dependent on the demand or activity of a root system (Hopkins, 1999).

Dehydrogenases are critical mitochondrial enzymes involved in energy production in respiration that are used in growth, nutrient uptake, and tissue maintenance (Hopkins, 1999). Dehydrogenase enzyme activity is a general measure of tissue respiratory activity, and has been used to quantify root respiratory activity or viability (Knievel, 1973). Some dehydrogenases such as glutamate dehydrogenase are also involved in nitrogen metabolism (Beevers and Hageman, 1969). In the present study, root dehydrogenase activity for both cultivars decreased to the lowest level in $\mathrm{Au}-$ gust 1999 (only 33\% of the level in May) and then increased in October through November to $85 \%$ of the level in May (Fig. 5A). In 2000, dehydrogenase activity decreased to the lowest level in late June, remained low through September, and then recovered in October (Fig. 5B). These results indicated that energy production through respiration and nitrogen metabolism in roots for creeping bentgrass were limited during summer months. Nelson and Treharne (1973) reported that activity of the respiratory enzymes such as malate dehydrogenase and isocitrate dehydrogenase in tall fescue (Festuca arundinacea Schreb.) decreased with increasing temperatures. Decreased dehydrogenase activity has been associated with heat stress damages (Kaur and Nainawatee, 1989).

Nitrogen uptake and metabolism is the main limiting step in amino acid and protein production, which has significant impact on plant response to environmental stresses (Beevers and Hageman, 1969). In 1999, ${ }^{15} \mathrm{~N}$ content was evaluated in August and October (Table 1). ${ }^{15} \mathrm{~N}$ content was $72 \%$ higher in October 1999 than that in August for both cultivars. In $2000,{ }^{15} \mathrm{~N}$ content was measured monthly from May to October(Fig. 6). The content of ${ }^{15} \mathrm{~N}$ was highest in May, decreased to the lowest level in July and August, and increased in October for both cultivars. Nitrate reductase is the key enzyme in nitrate assimilation and plant development (Beevers and Hageman, 1969), and is sensitive to high temperatures (Lauri and Stewart, 1993; Onwueme et al., 1971). Nitrate reductase activity of roots was measured monthly from May to October in 2000 (Fig. 7). Lowest NR activity was observed in August for L-93 and in September for Penncross. Both ${ }^{15}$ Nitrogen content and NR activity decreased during summer. These data indicated that both root nutrient uptake and assimilation activities were inhibited when creeping bentgrass experienced high temperatures during summer. Younis et al. (1965) found that an increase in temperature from 30 to $35^{\circ} \mathrm{C}$ caused a $60 \%$ to $70 \%$ decrease in NR activity in young corn (Zea mays L.) plants. The reduction in nitrogen uptake and assimilation activities under high temperatures could be related to the limited carbon supply to roots during summer as described above. Sullivan et al. (2000) demonstrated that the ability of roots to assimilate nitrate depends on carbohydrate supply from shoots in tall fescue. Greef and Geisler (1991) also found a high level of sugars induced a high nitrogen uptake in corn.

Cultivar variation in turf quality, root growth, and metabolic activities. Previous studies demonstrated that L-93 was more heat tolerant than Penncross (Xu and Huang 2000, 2001). Similar to previous reports, turf quality was higher for L-93 than for Penncross on most measurement dates in both years, rang-
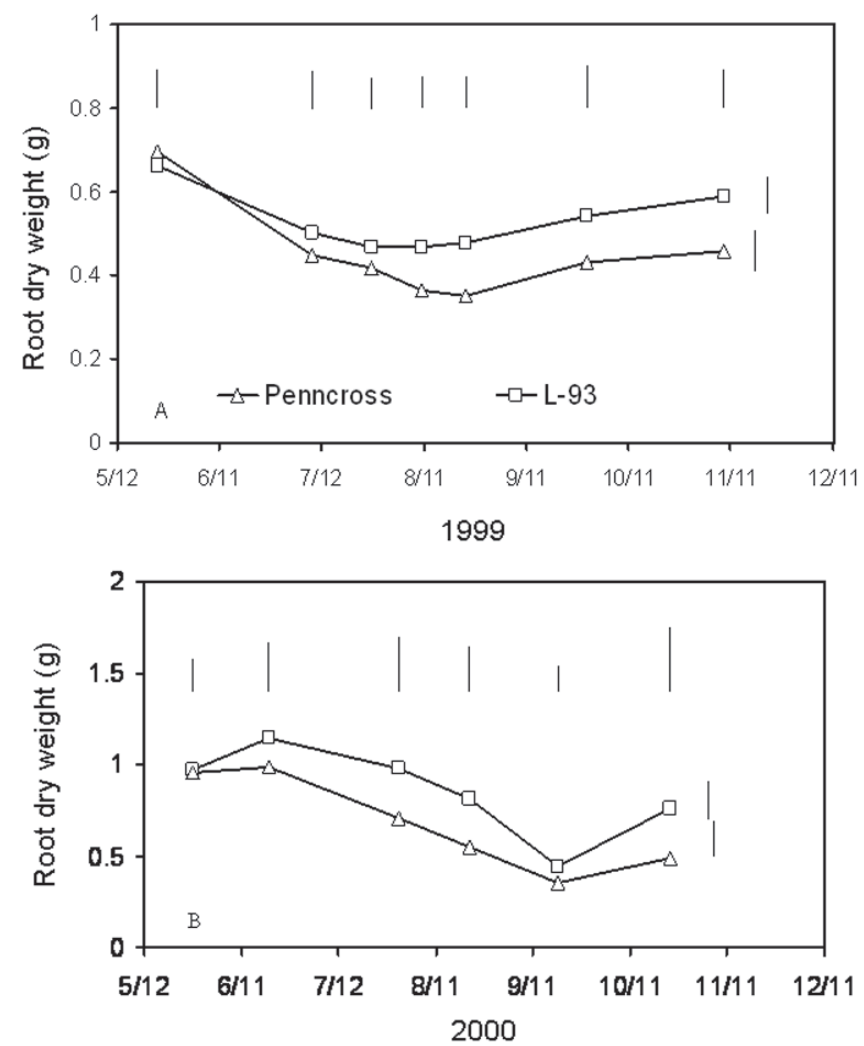

Fig. 3. Seasonal changes in root dry weight for two creeping bentgrass cultivars, L-93 and Penncross, in 1999 (A) and 2000 (B). Root dry weight was the weight of roots collected from a $393 \mathrm{~cm}^{3}$ soil in the surface $20-\mathrm{cm}$ soil. Vertical bars on the top indicate LSD values $(P<0.05)$ for cultivar comparison at a given date of year. Vertical bars on the right indicate LSD values $(P<0.05)$ for seasonal changes for a given cultivar.
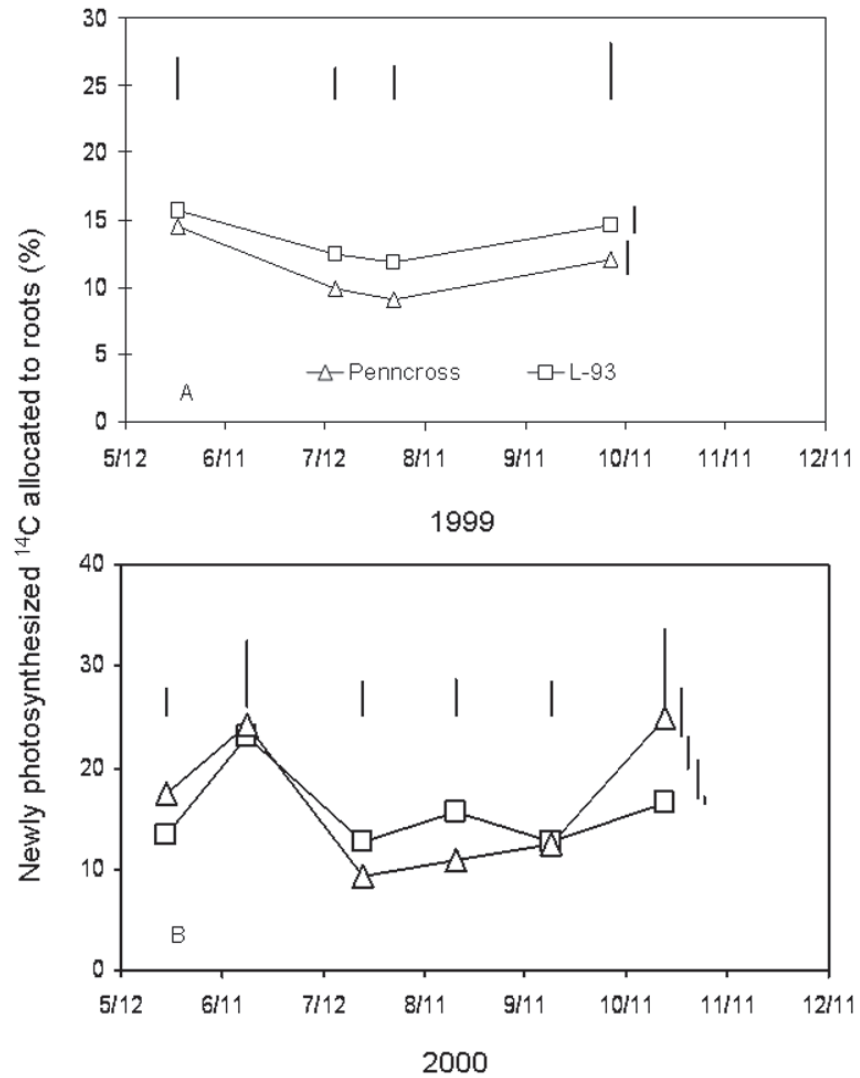

Fig. 4. Seasonal changes in carbon allocation to roots for two creeping bentgrass cultivars, L-93 and Penncross, in 1999 (A) and 2000 (B). Vertical bars on the top indicate LSD values $(P<0.05)$ for cultivar comparison at a given date of year. Vertical bars on the right indicate LSD values $(P<0.05)$ for seasonal changes for a given cultivar. 


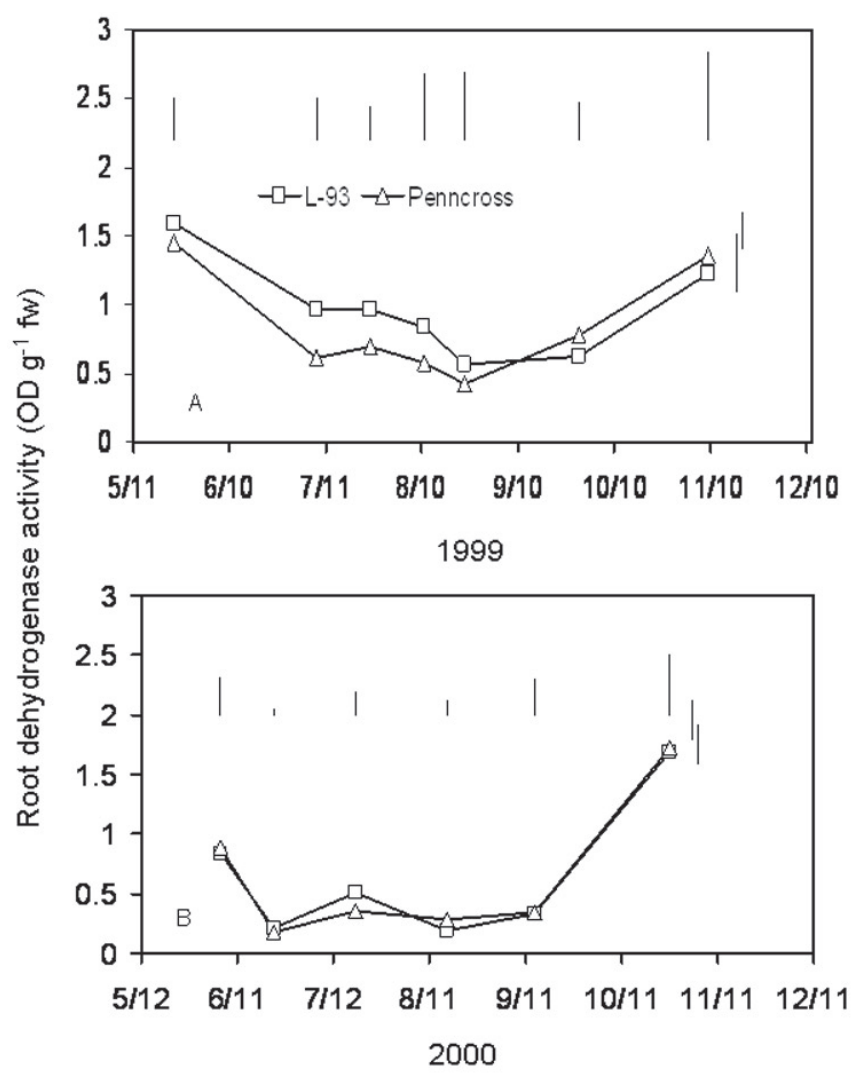

Fig. 5. Seasonal changes in root dehydrogenase activity for two creeping bentgrass cultivars, L-93 and Penncross, in 1999 (A) and 2000 (B). Vertical bars on the top indicate LSD values $(P<0.05)$ for cultivar comparison at a given date of year. Vertical bars on the right indicate LSD values $(P<0.05)$ for seasonal changes for a given cultivar.

ing from 5.7 to 8.6 for L-93 and from 5.0 to 7.8 for Penncross in 1999 and from 6.2 to 8.6 for L-93 and 4.0 to 7.5 for Penncross in 2000 (Fig. 2A and B). Cultivar difference was most pronounced during summer months in 2000 (Fig. 2B). L-93 had a greater root dry weight than Penncross from August to November 1999 and in July and August 2000. Lehman and Engelke (1991) reported that creeping bentgrass cultivars that produce more roots and deeper roots were better able to survive intensive heat. Bonos and Murphy (1999) found that heat-tolerant Kentucky bluegrass (Poa pratensis L.) cultvars had more roots than heat-sensitive cultivars.

Development of deep, extensive root systems (larger root mass or length) is often emphasized as an important factor in plant growth and adaptation to environmental stresses. Cultivar differences in turf quality dur-

Table 1. Root ${ }^{15} \mathrm{~N}$ uptake for two cultivars of creeping bentgrass, L-93 and Penncross, in August and October 1999. Data for 2000 was presented in Fig. 6.

\begin{tabular}{lcc}
\hline & \multicolumn{2}{c}{${ }^{15} \mathrm{~N}\left(\mathrm{ng} \cdot \mathrm{g}^{-1}\right.$ dry wt) } \\
\cline { 2 - 3 } Cultivar & $3 \mathrm{Aug}$. & 8 Oct. \\
\hline L-93 & $44.02 \mathrm{aB}^{\mathrm{z}}$ & $73.53 \mathrm{aA}$ \\
Penncross & $34.01 \mathrm{bB}$ & $60.61 \mathrm{bA}$ \\
\hline
\end{tabular}

${ }^{\mathrm{z}}$ Means followed by the same lower case letters within a column or the same upper case letters within a row were not significantly different based on LSD test at $p=0.05$. creeping bentgrass. $86: 525-531$

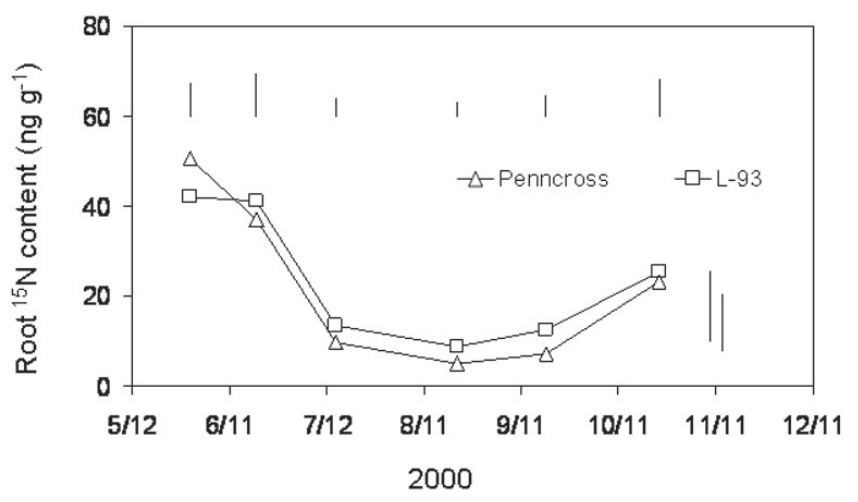

Fig. 6. Seasonal changes in ${ }^{14} \mathrm{~N}$ uptake for two creeping bentgrass cultivars, L-93 and Penncross, in 2000. Data for 1999 was presented in Table 1. Vertical bars on the top indicate LSD values $(P<0.05)$ for cultivar comparison at a given date of year. Vertical bars on the right indicate LSD values $(P<$ 0.05 ) for seasonal changes for a given cultivar.

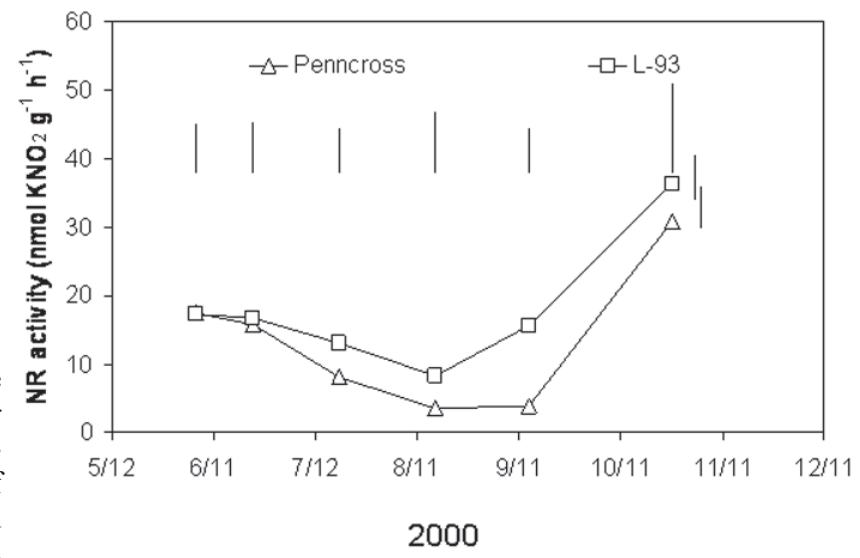

carbon allocated to roots was $29 \%$ higher in L-93

than in Penncross in July and August in both years (Fig. 4A, B), reflecting higher carbon metabolism in roots of L-93. L-93 also had higher dehydrogenase activity than Penncross in July 1999 (Fig. 5A); however, no significant difference in root dehydrogenase activity was detected between the two cultivars in 2000 (Fig. 5B). Root ${ }^{15} \mathrm{~N}$ content was $29 \%$ and $21 \%$ higher in L-93 than in Penncross in August and October 1999, respectively (Table 1); in $2000,{ }^{15} \mathrm{~N}$ content was also higher for L-93 than for Penncross in August and September (Fig. 6). L-93 also had a greater NR activity than Penncross in September 2000 (Fig. 7). These results suggested roots of L-93 not only were more extensive than Penncross, but also were able to maintain higher nitrogen uptake and assimilation activities than roots of Penncross during summer months. The larger root system in combination with high metabolic activities could contribute to better heat tolerance for

\section{Literature Cited}

BassiriRad, H. and M.M. Caldwell. 1992. Temporal changes in root growth and $15 \mathrm{~N}$ uptake and water relations of two tussock grass species recovering from water stress. Physiol. Plant.

Beard, J.B. 1973. Turfgrass: Science and culture. Prentice-Hall, Engle-wood Cliffs, N.J.

Beevers, L. and R.H. Hageman. 1969. Nitrogen reduction in higher plants. Annu. Rev. Plant
Fig. 7. Seasonal changes in nitrate (NR) reductase activity for two creeping bentgrass cultivars, L93 and Penncross, in 2000. Vertical bars on the top indicate LSD values $(P<0.05)$ for cultivar comparison at a given date of year. Vertical bars on the right indicate LSD values $(P<0.05)$ for seasonal changes for a given cultivar.

Physiol. 20:495-522.

Bonos, S., and J.A. Murphy. 1999. Growth responses and performance of Kentucky bluegrass under summer stress. Crop Sci. 39:770-774.

Bushoven, J.T. and R.J. Hull. 2001. Nitrogen use efficiency is linked to nitrate reductase activity and biomass partitioning between roots and shoots of perennial ryegrass and creeping bentgrass. Intl. Turfgrass Res. J. 9:245-252.

Bushoven, J.,Z. Jiang, and R. Hull. 2002. Differences in nitrate uptake and metabolism between perennial ryegrass and creeping bentgrass cultivars. Turf. Environ. Res. Online. 1:1-13.

Greef, J.M. and G.H. Geisler.1991. Nitrate uptake in response to soluble carbohydrates from roots and shoots of young maize plants (Zea mays L.), p 73-80. In B.L. McMichael and H. Persson (eds.). Plant roots and their environment. Elsevier Sci. Pub. Inc., New York.

Hopkins, W. 1999. Plant Physiology. John Wiley and Sons, Inc., New York.

Huang, B., G.B. North, and P.S. Nobel. 1993. Soil sheaths, photosynthate distribution to roots, and rhizosphere water relations for Opuntia ficusindica. Int. J. Plant Sci. 154:425-431. tion, and carbon allocation of two cool-season perennial grasses in response to surface soil
Huang, B. and J. Fu. 2000. Photosynthesis, respira- 
drying. Plant Soil 227:17-26.

Huang B. and Q. Xu. 2000. Root growth and nutrient element status of creeping bentgrass cultivars differing in heat tolerance as influenced by supraoptimal shoot and root temperatures. J. Plant Nutr. 23: 979-990.

Huang, B. and X. Liu. 2003. Summer root decline: production and mortality for four cultivars of creeping bentgrass. Crop Sci. 43:258-265.

Karnok, K.J. and R.T. Kucharski. 1980. Seasonal root responses of Poa annua and creeping bentgrass while maintained under putting green conditions, p. 80-84. In: J.R. Street (ed.) Ohio Turf. Conf. Proc., Columbus, Ohio, 2-4 Dec. 1979. Ohio Agr. Res. Dev. Ctr., Wooster, Ohio.

Kaur, J. and H.S. Nainawatee. 1989. Malate dehydroganse activity of leaves of a thermotolerant Triticum aestivum mutant. Biochem. Physiol. Der Pflanzen. 185:277-280.

Knievel, D.P. 1973. Procedure for estimating ratio of live to dead root dry matter in root core samples. Crop Sci. 13:124-126.

Koski, A.J. 1983. Seasonal rooting characteristics of five cool-season turfgrasses. MS thesis. Ohio
State Univ., Columbus.

Lauri, S. and G.R. Stewart. 1993. Effects of nitrogen supply and high temperature on the growth and physiology of the chickpea. Plant Cell Environ. 16:609-621.

Lehman, V.G. and M.C. Engelke. 1991. Heritability estimates of creeping bentgrass root systems grown in flexible tubes. Crop Sci. 31:1680-1684.

Nelson, C.J. and K.J. Treharne. 1973. Photosynthetic and respiratory enzymes in Festuca. Welsh Plant Breeding Sta. Rpt. 15.

Onwueme, I.C., H.M. Laude, and R.C. Huffaker. 1971. Nitrate reductase activity in relation to heat stress in barley seedlings. Crop Sci. 11:195-200.

Schlossberg, M.J., K.J. Karnok, and G. Landry, Jr. 2002. Estimation of variable root-length density of heat-tolerant 'Crenshaw' and 'L-93' creeping bentgrass by an accumulative degree-day model. J. Amer. Soc. Hort. Sci. 127:224-229.

Sullivan, W.M., Z. Jiang, and R.J. Hull. 2000. Root morphology and its relationship with nitrate uptake in Kentucky bluegrass. Crop Sci.
40:765-772.

Sweeney, P., K. Danneberger, D. Wang, and M. McBride. 2001. Root weight, nonstructural carbohydrate content, and shoot density of highdensity creeping bentgrass cultivars. HortScience 36:368-370.

Thornton, B. and P. Millard. 1997. Increased defoliation frequency depletes remobilization of nitrogen for leaf growth in grasses. Ann. Bot. 80:89-95.

$\mathrm{Xu}, \mathrm{Q}$. and B. Huang. 2000. Growth and physiological responses of creeping bentgrass to changes in air and soil temperatures. Crop Sci. 40:1363-1368.

Xu, Q. and B. Huang. 2001. Morphological and physiological characteristics associated with heat tolerance in creeping bentgrass. Crop Sci. 41:127-133.

Younis, M.A., A.W. Pauli, H.L. Mitchell, and F.C. Stickler. 1965. Temperature and its interaction with light and moisture in nitrogen metabolism of corn (Zea mays L.) seedlings. Crop Sci. $5: 321-326$. 